INTERNATIONAL JOURNAL OF RESEARCHES IN BIOSCIENCES, AGRICULTURE AND TECHNOLOGY (C) VISHWASHANTI MULTIPURPOSE SOCIETY (Global Peace Multipurpose Society) R. No.MH-659/13(N) www.vmsindia.org

\title{
MICROCRYSTALLINE PARAMETER AND ELECTRICAL CONDUCTIVITY OF ALUMINIUM AND COBALT (AL - CO) MIXED LITHIUMFERRITES
}

\section{Suresh. S. Darokar}

Science College, Congress Nagar. Nagpur-12,India. sureshdarokar@gmail.com

\section{Abstract:}

A new series oflithium hardferrite ( M- type) with the substitution of aluminium and cobalt weresynthesized withgeneral chemical formula $\mathrm{Li}_{0.5} \mathrm{Fe}_{0.5+\mathrm{x}} \mathrm{Al}_{12-2 \mathrm{X}} \mathrm{Co}_{\mathrm{xO}} \mathrm{X}_{19}$ (wherex $=1,2,3,4$ and 5 ) using reacting oxide by high temperature solid state reaction technique. The crystalinel characterization of compound has been carried out from X-Ray diffraction powder pattern. The compounds are in single hexagonal phase without traces of uncertainly ambiguous reflection. From XRD pattern lattice parameters has recorded with increasing doped aluminum element in the range from $\mathrm{a}=5.807 \AA$ to $5.906 \AA$ and $\mathrm{c}=22.507 \AA$ to $22.585 \AA$ pertaining the space group $\mathrm{P}_{3} / \mathrm{mmc}$ (No.194). The mass density of the ferrites were found linearly varies and depends upon the mass and volume of sample. The X-Ray density has depends upon the lattice constant and molecular weight of the compounds. The average particle size was also estimated.. work The electrical conductivitywere studied andthe values are obtained in the range $2.193 \times 10^{-12}$ to $5.78 \times 10^{-6} \Omega^{-1} \mathrm{~cm}$ for Li-ferrite.

Keywords: Magnetoplumbite, electrical conductivity, Activation Energy.etc.

\section{Introduction:}

A new series of lithium hexaferrites $\mathrm{Li}_{0.5} \mathrm{Fe}_{0.5+\mathrm{x}} \mathrm{Al}_{12-2 \mathrm{x}} \mathrm{CoxO}_{19}$ mangnetoplumbite has been a great technological interest in many electromagnetic devices from a long time. High electrical resistivity, low eddy current losses, low magnetic losses, and very good thermal and chemical stability. Lithium ferrite material has a great importance for microwave applications. In the family of hexagonal ferrites, the Mangnetoplumbite hexaferrites (M-Type) created much attention due to wide range of application in industries and created potential to interest in technological and scientific research due to their application importance such as high density magnetic recording, microwave device materials, hard disc in computer system. The application need particularly magnetic and electrical specification with the view, many attempt have been improved the properties of hexagonal ferrites using different tract of additives. The calcium hexferrites [1-6] have magnetic properties comparable to $\mathrm{BaM}$ and $\mathrm{Sr} \mathrm{M}$. In Calcium ferrites many attempt has been made to replace $\mathrm{Fe}^{+3}$ ions with $\mathrm{Al}^{+3}, \mathrm{Cr}^{+3}$ and $\mathrm{Co}^{+3}$ etc. A compound with the combination of bivalenttetravalent cation was also used to replace $\mathrm{Fe}^{+3}$ ion such as $\mathrm{Cu}-\mathrm{Ti}, \mathrm{Co}-\mathrm{Ti}, \mathrm{Co}-\mathrm{Sn}, \mathrm{Zn}-\mathrm{Sn}$ etc $[7,8]$ without any appreciable change in BaM structure. When $\mathrm{Fe}^{+3}$ ions are replace by non magnetic ions like $\mathrm{Ti}^{+4}$ and $\mathrm{Sn}^{+4}$ etc. In the same way Lithium ferrites substituted with $\mathrm{Al}$ and Co has been studied structurally, electrically and magnetically [9]. In the present studyaseries of five samplewithchemicalformula $\mathrm{Li}_{0.5} \mathrm{Fe}_{0.5+x} \mathrm{Al}_{12}$ ${ }_{2} \mathrm{xCoxO}_{19} \quad(\mathrm{x}=2, \quad 3,4,5$ and 6) wereprepared.Lithium ferrites have attracted considerable attention because of the squareness of hysteresis loop coupled with superior temperature performance the crystal structure of M-typAe like compound with a space group $\mathrm{P}_{3} / \mathrm{mmc}$ (194)can be described as superposition of two structure block namely Rblock with composition $\mathrm{BaFe}_{6} \mathrm{O}_{11}$ and S-block with composition $\mathrm{Fe}_{6} \mathrm{O}_{8}$ [10] in the stoichiomatric ratio.

\section{Material and Methods:}

All the polycrystalline powder sample were synthesized by high temperature solid state reaction using A.R grade oxides withstoichiomatric ratio $\mathrm{Li}_{2} \mathrm{O}, \mathrm{Fe}_{2} \mathrm{O}_{3}, \mathrm{Al}_{2} \mathrm{O}_{3}$ and $\mathrm{Co}_{2} \mathrm{O}_{3}$ mixture. $\mathrm{Li}_{2} \mathrm{O}$ oxide was carefully dehydrated before the mixing procedure. After grinding the mixture under acetone acid for six hours. During the preparation of pellets of thoroughly grounded mixture in the proper molar ratio with $5 \%$ of PVA as a binder are prepared by applying 10 tone pressure per square inch. These pallets slowly heated in the furnace at $600{ }^{\circ} \mathrm{C}$ for 5 - 6 hours to remove binder. Then it was fired at $1200{ }^{\circ} \mathrm{C}$ for 120 hours continuously, after that the furnace were cooled at the rate of $20^{\circ} \mathrm{C}$ per hours up to 1000 ${ }^{\circ} \mathrm{C}$ and then $50^{\circ} \mathrm{C}$ per hours and then cooled in natural way the phase of final sample were verified by Philips X-ray diffrectometerusing Nfilter copper radiation. The mean grain size of multicrystalline samples was in the range 150 $200 \mathrm{~A}^{0}$. All the samples show single phase formation with a space group $\mathrm{P}_{3} / \mathrm{mmc}$ (194). Xray pattern of the samples as shown in fig. 1.1

The D.C resistivity was measure by the methods using LCR meter / $Q$ meter.[11]. The end faces of pellets were coated with thin layer of conducting silver paste and measurement were made from room temperature to $800 \mathrm{~K}$ Thermoelectric power measurement were carried 
out after sandwiching the thick pellet between two copper rod from room temperature to $550^{\circ} \mathrm{C}$

\section{Result and discussion:}

In the present work, the Cobalt and Aluminium substituted lithium hexaferrites were introduced with general formula $\mathrm{Li} 0.5 \mathrm{Fe}$

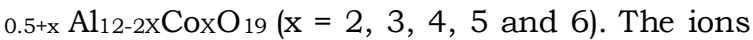
in Ba-M compounds can be replaced partly by $\mathrm{Co}^{+3}$ or completely $\mathrm{Li}^{+1}$ and combination of $\mathrm{Fe}^{+3}$ and $\mathrm{Al}^{+3}$ ions without changing the crystal lattice symmetry [12]. In all the specimens substituted ions would be chosen to keep electrical neutrality and to have similar ionic radii in these ferrites. The Cobalt and Aluminium play an important role in the property variation. XRD technique is used to confirms the formation of hexagonal $\mathrm{M}$ structure of compounds belonging to a space group $\mathrm{P}_{3} / \mathrm{mmc}$ (194)Homawalt 1956

Due to the resemblance of ionic radii of $\mathrm{Fe}^{+3}$ with $\mathrm{Co}^{+3}$ and $\mathrm{Al}^{+3}$ ions $[13,14]$. The ferrites ions will replace by cobalt and aluminium. It is seen that former ions are very easily replaced at any substituted variation in all specimens [15]. The hexagonal lattice parameters ' $a$ ' and ' $c$ ' decreases linearly with the substitutional variation $\mathrm{CO}^{+3}$ and $\mathrm{Fe}+3$ concentration in all specimens. The decrease in lattice parameters due to close packing of lattices in the materials [16-18]. The decrease inlattice parameter and cell volume agree with result for $\mathrm{Ba} / \mathrm{Sr}$ ferrite [19-20]. The numerical values of compositional data such as lattice constant, cell volume and $\mathrm{X}$ - ray density are tabulated in table -1 . The observed value of electrical conductivity, activation energy and curie molar constant for specimens are also tabulated in table - 2

The plot of $\ln \sigma$ vs $(1 / \mathrm{T}) \times 10^{-3} \mathrm{~K}$ for the entire sample was almost linear. The electrical conductivity of these ferrites increases with increasing ferrite ion concentration. The electrical conductivity of sintered specimens varies from to $2.193 \times 10^{12} \Omega^{-1} \mathrm{~cm}$ to $5.78 \times 10^{-6}$ $\Omega^{-1} \mathrm{~cm}$ of these ferrites. The other workers have obtained a conductivity value of $2 \times 10^{-2} \Omega^{-1} \mathrm{~cm}$ for Li-ferrite that obtained is $2.3 \times 10^{-6} \Omega^{-1}$ $\mathrm{cm}[21]$

In this present work the electrical conductivity value obtained for the compounds are $2.193 \times 10^{-12}$ to $5.78 \times 10^{-6} \Omega^{-1} \mathrm{~cm}$. The value of the conductivity may be partly attributed to the low evaporation of lithium from the sample prepared different from these of Rozlescu etal 1974 and Venugopal Reddy 1981.The variation of activation energy with the substitutionalvariable parameters $\mathrm{x}$-may be explain on the basis of Vewrway model [22-24], a small number of ferrous ions $\left(\mathrm{Fe}^{+2}\right)$ are generally developed during sintering process which lead the conductivity in ferrites suggestingthe hopping mechanism according $\left(\mathrm{Fe}^{+2}-\mathrm{Fe}^{+3+\mathrm{e}^{-}}\right) \quad[25,28]$. However these transition take place for a very small interval of time and are not detectable by the ordinary method .This valence exchange mechanism of Verwey may be considered for these ferrites as general applicableto M-type ferrite.

Table 1: Crystallographic structural data of lithium hexaferrites

\begin{tabular}{|l|l|l|l|l|l|}
\hline \multirow{2}{*}{ Compounds } & \multicolumn{2}{|l|}{ Lattice parameters } & \multirow{2}{*}{ Cell Volume $\left(\mathrm{A}^{0}\right)^{3}$} & $\begin{array}{l}\text { Mol. Wt } \\
\text { gm }\end{array}$ & $\begin{array}{l}\text { X-RayDensity } \\
\text { gm/cc }\end{array}$ \\
\cline { 2 - 3 } & $a\left(\mathrm{~A}^{0}\right)$ & $\mathrm{c}\left(\mathrm{A}^{0}\right)$ & 663.81 & 780.89 & 3.9065 \\
\hline $\mathrm{Li}_{0.5} \mathrm{Fe}_{2.5} \mathrm{Al}_{8} \mathrm{Co}_{2} \mathrm{O}_{19}$ & 5.859 & 22.323 & 66.26 & 1024.42 & 5.6963 \\
\hline $\mathrm{Li}_{0.5} \mathrm{Fe}_{6.5} \mathrm{Co}_{6} \mathrm{O}_{19}$ & 5.695 & 21.262 & 597.22 & \\
\hline
\end{tabular}

Table 2: Electricalconductivity parameters of compounds

\begin{tabular}{|l|l|l|l|}
\hline Compounds & $\begin{array}{l}\text { Electrical Resistivity } \\
\text { at room temperature } \Omega \mathrm{cm}^{-1}\end{array}$ & $\begin{array}{l}\text { Activation energy } \\
\mathrm{E} \text { in }(\mathrm{eV})\end{array}$ & $\begin{array}{l}\text { Electrical Conductivity } \\
\text { at room temperature. } \\
\Omega^{-1} \mathrm{~cm}\end{array}$ \\
\hline $\mathrm{Li}_{0.5} \mathrm{Fe}_{2.5} \mathrm{Al}_{8} \mathrm{Co}_{2} \mathrm{O}_{19}$ & $4.559 \times 10^{11}$ & 0.77 & $2.193 \times 10^{-12}$ \\
\hline $\mathrm{Li}_{0.5} \mathrm{Fe}_{6.5} \mathrm{Co}_{6} \mathrm{O}_{19}$ & $1.72 \times 10^{5}$ & 0.39 & $5.78 \times 10^{-6}$ \\
\hline
\end{tabular}

\section{Conclusion:}

In this present work, the formation of lithium hardferrites containing $\mathrm{Al}^{+3}$ and $\mathrm{Co}^{+3}$ ions along with $\mathrm{Fe}^{+3}$ ions were checked. All these compounds have M-structure through the site distribution changes. No changes occur in the charge distribution but the site distribution is change due to strichiometric changes.

The electrical conductivity of $\mathrm{Li} 0.5 \mathrm{Fe}$ $0.5+x \mathrm{Al}_{12-2 \mathrm{x}} \mathrm{Cox}_{19}$ at different concentrations has been explained on the basis of the hopping mechanism of holes (Co ${ }^{2+}$ and $\mathrm{Co}^{3+}$ ) and electrons $\left(\mathrm{Fe}^{2+}\right.$ and $\mathrm{Fe}^{3+}$ ). As evident from the change in slope of the Arrhenius plot at temperature

The temperature variation in the dc electrical conductivity of pure $\mathrm{Li}_{0.5} \mathrm{Fe}_{6.5} \mathrm{Co}_{6} \mathrm{O}_{19}$ and mixed $\mathrm{Li} 0.5 \mathrm{Fe}_{2 .} \mathrm{Al}_{8} \mathrm{Co}_{2} \mathrm{O}_{19}$ shows a definite kink, which corresponds to ferromagnetic to paramagnetic transitions. The activation energy in the paramagnetic region is higher than the 
ferromagnetic region. Ferrites with the presence of Co leads to a decrease in activation energy and a decrease in conductivity because there is a significant decrease in crystallite shape area. The presence of Co in ferrites leads to disorder and hence to localization of electrons, leading to the metal-insulator transition-like properties of the Anderson model. The lattice disorder plays a significant role in determining dc conductivity behavior of such ferrites.

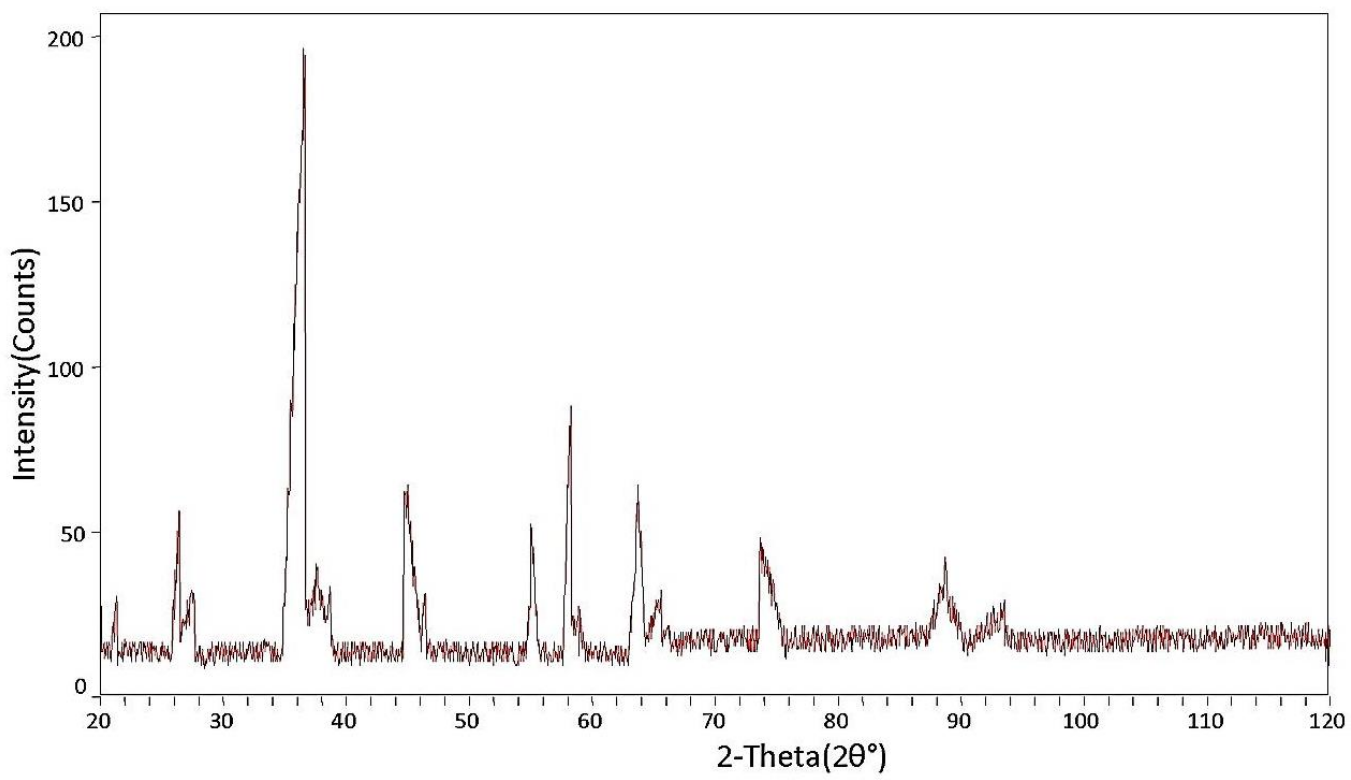

Fig.1: XRD of compound $\mathrm{Li}_{0.5} \mathrm{Fe}_{2.5} \mathrm{Al}_{8} \mathrm{Co}_{2} \mathrm{O}_{19}$

\section{References:}

1. J. Beretea and T. Brown. Austral. J. Chem. 24(1971) 273.

2. J.Lipka,A. Gruskova, O.Orlicky, J.Siteck, M.Miglierini, R.Grone, M.Hud and Toth Hyperfine Interaction 59(1990) 381.

3. G.Albanese, A Deriu, E.Luchini and G.Slokar.Appli Phys A 2(1981) 45.

4. R.Muller, H.Pfeiffer and W.Schuppet, J.Mogn.Mogn Mater 18 (1991)101.

5. D.K.Kulkarni and C.S.Prakash Bull Mater Sci.17(1994) 35.

6. G.Asti. M.Carbuccocchio. A Deriu, E.Lucchini and G.Slokar, J.Mogn mogn Mater 20(1980)44.

7. J.G.Renson, J.A.Schullces and J.S.Van.WIering, J.Phys Collog 32(1971) C 1924.

8. B.X.Gu,H.Y.Zang.H.R.Zhai,B.G.Slen,M.Lu,S. Y.Zhang,J Phys State Sol 133 (1992) K83.

9. Hanmawalt (1936) International table for Xray diffraction photograph.

10. X.Obrador, A Isalgue, A Collomb, A Tejeda, J.C.Joubert, J.,PhysC. 19(1986) 6605

11. D.B.Ghare, A.P.B.Sinha, J.Phys Chem Solid 29(1958) 885.

12. K.Haneda, H.Kojima. Phys State Solid (A) 6(1971) 256.

13. .Kanke E, Takayama Muromachi Y.Uchida, Kato \& S.Takikawa, J.Solid state Chem 95(1991) 43.

14. L.G.Van Uitert, J. Appl. Phys 28.1 (1957)317.

15. C.S.Prakash and D.K.Kulkarni Ind J.Appl.Phys 32(1994) 368
16. K.G.Rewatkar,

C.S.Prakash and D.K.Kulkarni Mater Sci.Lett 28(1995) 365.

17. Isalgue, A Laberta, J.Tejada, X Obradir. Appl.Phys A39(1986) 221.

18. S.S.Darokar, K.G.Rewatkar and D.K.Kulkarni Mater Chem.Phys.56 (1998) 84-85.

19. K. Haneda, M. Kojima, J. Appl. Phys 14.B(1973) 3760.

20. V. Adelskod, Arkir Kemi Min Geo 12 A (1938) 1.

21. Albense G, Carbulichhio and Deril A J.Phys Solid State: A 23 (1974) 351.

22. Z.Redrigue, Obradors X, Labrata A, Tejeja.J.Pernet M. M.Solid Paul and J.Tholente, J. Phys Collog 149 (1988) 119.

23. J.M.Verstegen D.T.J.Solid State Chem 1(1973) 468.

24. E.J. Verway J.H, De-Bar.Pec.Trar.Chem Pay Bull 55 (1936)531

25. A.R.Lamani1,H.S.Jayanna1,P.Parameswara \&R.Somashekar.J.Mater.Res.Innov.(2011)15 No.3, 186 .

26. N.Rezlescu, D.Condurachi, P.Petrarju and E.Lucca, J.A.M .Ceream Soc.57(1974)40.

27. T. T..Fang, J.B.Hawan and F.S.Shiun, J.Mater ci Lett 11 (1992) 127.

28. S.S.Darokar,K.G.Rewatkar,M.S.Chowkase \& D.K.Kulkarni,Indian J.Phys74A (2000) 155-157.

29. Suresh. S. Darokar et.al, J. Adv. Appl. Sci. Res, 2013, 4(1): 173-177. 